\title{
CREATIVE E-COURSE MODEL IN ENGLISH FOR ENGINEERING STUDENTS
}

\section{Summary}

Introduction

A topical task is to research the methodology of designing an online course in English for Specific Purposes (ESP) to foster students' communicative and creative thinking skills in their integrity.

\section{Aim of the Study}

To design a creative online course model in ESP for engineering students.

\section{Materials and Methods}

Ministry of Education and Science of Latvia, and Riga Technical University project "Development of Online Course Design and Delivery Approach in Creative Learning of ESP”.

\section{Results}

The set of criteria developed in designing a creative online ESP course may be also applied in other languages, and includes specific course content, creative process support and corresponding course administration.

\section{Conclusions}

The suggested model is integrated and complex, and enables development of students 'professional, communicative and thinking skills.

Key words: ESP, online course design, activity theory, creative problem solving.

\section{Introduction}

One of the key challenges facing the higher education system is to change the prevailing culture so that greater value is placed on students' creative development alongside with more traditional forms of academic development (Jackson, 2006; Lantolf, 2006; Laurillard, 2002; etc.). "Although, students are expected to be creative, creativity is rarely an explicit objective of the learning and assessment process (except for a small number of disciplines in the performing and graphic arts" (Jackson, 2006). To be successful, Sternberg and Lubart point out the following three abilities: analytical abilities - to analyse, evaluate, judge, compare and contrast; practical abilities - to apply, utilise, implement and activate; and creative abilities - to imagine, explore, synthesize, connect, discover, invent and adapt (Sternberg, Lubart in Jackson, 2006). D. Laurillard specifies that "adaptive learning" must be joined by "generative learning" - learning that enhances our capacity to create (Laurillard, 2004). These goals can be largely attained by a wider introduction of e-learning (Benfield, Francis, 2005; Porter, 2006). Besides the generally recognized benefits such as content individualisation, increased autonomy, multisensory delivery of information, flexibility in time, place and tempo of learning, e-learning can offer a creative medium for self-expression of individuality and fruitful collaboration.

With "shared knowledge building" and "discovery-based learning" gaining ground, the 
curricula of schools and universities are becoming increasingly student-centered. The author acknowledges that everyone has the potential to be creative, and that individual creativity depends greatly on the social, cultural, family, pedagogical, and even the virtual (as in the case of e-learning) environments (Rumpite, 1998, 2000). Therefore, the research project supported by the Ministry of Education and Science, Latvia, and Riga Technical University (RTU), Latvia, pursued the goal of integrating creative learning methodology with e-learning in the online course of English for Specific Purposes (ESP) for engineering students.

\section{Aim of the Study}

1. to analyze the main methodological approaches and tools in developing creativity and explore the integration of ICT facilities with creative learning methodology of ESP

2. to develop an online course design and delivery approach in creative learning of ESP for engineering students

3. to design the online course contents (texts, tasks, creative problem solving situations, tasks and activities, creative thinking techniques)

4. to integrate development of students' language skills with purposeful fostering of their creative thinking skills

5. to test and implement the online course delivery; to analyze the project results

\section{Materials and Methods}

Adopted goals and targets determine the scope, content, quality, development complexity and, eventually, the accessibility of the specific e-learning project. The goals of the Ministry of Education and Science, Latvia, and RTU, Latvia, project "Development of Online Course Design and Delivery Approach in Creative Learning of ESP" were drafted in the context of the "Strategic Development Plan of Latvia", development of the Virtual University in Latvia, and the widely recognized notion that creative thinking skills may have a crucial impact on student performance in academic and professional tasks. These goals implied the purposeful development of students' professional and communicative skills through the use of creative thinking tools and techniques, both in virtual and face-to-face classes.

Creative e-learning is defined as the integration of creative learning methodology with elearning facilities to promote the creative abilities of our target audience (Rumpite, Zuga, Ritins, 2007). A creative activity in e-learning would largely depend on specific learning content and process design, which should also recognize the differences in personalities of its end users. Learners should have four key qualities:

1) the ability to identify new problems, rather than depend on others to define them;

2) the ability to transfer knowledge gained in one context to another in order to solve a problem;

3) a belief in learning as an incremental process, in which repeated attempts will eventually lead to success;

4) the capacity to focus attention in the pursuit of a goal, or set of goals (Craft, 2001).

Edward de Bono, the originator of lateral thinking and an acknowledged international authority in the field of creative thinking writes that "creativity need no longer be a mystery or a special gift - it is a skill that can be learned and applied" (Bono, 1996). He has always stressed the importance of escaping from ingrained patterns and stereotypical thinking and urged the need for a fresh approach to problem solving. It could help to formulate patterns in an innovative and exciting way, and lead to unordinary, theoretically and practically efficient solutions.

According to Torrance (1983), creativity is not a special, but a common ability, which is based on the constellation of the general intellect, personal features and abilities to think productively. He 
considered that any creative process consists of several steps - perceiving the problem, looking for a solution, generating and formulating hypotheses, verification of the hypotheses, their modification and finding a solution or a result. It is essential to make students realize that "all the knowledge of the world we live is tentative and open to movement ..." (Wells, 2002). When the aim is to foster creativity, there might be two recommendations. One is problem-solving activities, the second is to help students of greater promise find ways of accelerated intellectual development in the domain of their choice.

Knowledge building can take a variety of forms, but all are essentially social and interactional in nature (Wells, 2002). Therefore, one of the major developmental factors is the assimilation of social experience while interacting, in our case - in the computer-mediated collaborative environment. Csikszentmihalyi points out that while creativity originates in the minds, actions and interactions of individuals, it is fundamentally a social-cultural concept (Csikszentmihalyi, 1997).

\section{Methodological Approach}

The research was centered on the theoretical and empirical methodologies in defining and developing creativity in pedagogy, psychology and language teaching practice (Bono, 1996; Csikszentmihalyi, 1997; Lantolf, 2006; Lindquist, 2003; Runco, Pritzker, 1999; Sternberg, Lubart, 1999; Torrance, 1983, etc.). Several tendencies became apparent with focus basically either on the result - which should be innovative and socially meaningful (something new and useful), or a significant personality feature or a process. Still most of the contemporary researchers consider a creative personality, process and product in their entirety.

Vygotsky, the founder of the cultural-historical theory (Vygotsky, 1978; 1999), viewed the creative process as "interaction, tension, transformation, and synthesis over the parallel timescales of the creative act, the creative life, and historical cultural development" (Moran, John-Steiner, 2003). He underlined that creativity exists not only where it creates great historical works, but also everywhere human imagination combines, changes, and creates something new. He came to a far-reaching conclusion that "creativity creates the self as well as external artifacts" (Vygotsky in Moran, John-Steiner, 2003). In a Vygotskyan framework, we speak of a lifelong "zone of proximal development" as "past acts, current experiences, and future plans expand and mobilize the resources of creative individuals" (Ibid.). "Creativity forms lifelong zone of proximal development that contributes to the sustained development of creative personality" (Ibid.:78). Vygotsky considered that imagination is the mechanism of creativity. In adolescence, creative imagination is characterized by the collaboration of imagination and thinking in concepts, which matures in artistic and scientific creativity of adulthood. Therefore, it is significant to develop both imagination and abstract thinking. According to Vygotsky, we have to understand creativity in terms of collaboration and interaction. He stressed the social processes in creative endeavors.

His approach was further embodied in the activity theory (Леонтьев, 1977; Davydov, 1999; Гальперин, 2000; Engestrom, 1999; Lompscher, 1999, etc.); it noted that any kind of activity has its own definite content, structure, needs, motives, tasks and actions (operations). The activity to be developed is structurally analysed according to the hierarchy of the underlying actions in order to estimate the gradual controlled process of skill development.

Accordingly, to secure adequate selection of the online course material, the project developers analyzed the existing and future trends in the field of Power Engineering. The materials for the online course were selected on the basis of (1) the dynamic changes that are taking place in the students' field; (2) the needs analysis of the students; (3) students' functions as future engineers, focusing on their skill to create knowledge rather than to reproduce it; (4) the students' curriculum 
in majoring disciplines. The analysis of the field and the experts views on the findings indicated that one of the most essential issues that modern power engineering has to deal with is not only the application of modern technologies to optimize the use of the traditional energy sources, but also the steadily increasing role of renewable energy sources in the world. The content and organization of the online course reflected these findings. It resulted in a smaller number of texts and learning tasks; they had become more purposeful, corresponding to the generalized and most essential ('core') concepts and situations. The course content was also largely determined by the goals of the Erasmus project on the "Consumer Citizenship Education" (CCE) (http://www.hihm.no/concit), dealing with sustainable development of the environment and the role of a human in preserving it. Another feature to foster students' creativity was to develop their ability to see the whole earlier than its separate parts (Davydov, 1999; Давыдов, 1996, Гальперин, 2000, Lompscher, 1999, etc.); it was implemented in both the online and face-to-face learning. The criteria for designing and delivery of a creative online course in teaching languages are seen in Table 1 (see Table 1).

Table 1. Criteria for the design and delivery of a creative online course in foreign languages (Rumpite, Zuga, Ritins, 2007).

\begin{tabular}{|c|c|c|}
\hline Crit & teria & Practical implementation and delivery \\
\hline \multicolumn{3}{|c|}{ 1. $\quad$ Course content } \\
\hline & $\begin{array}{l}\text { Learning } \\
\text { material and } \\
\text { visuals }\end{array}$ & $\begin{array}{l}\text { - Modelling authentic communicative situations in the students' professional area, e.g. Power } \\
\text { Engineering } \\
\text { - Challenging content developed with student motivation and interests in mind } \\
\text { - Learning material containing a problem or a contradiction } \\
\text { - Sufficient material for thought, transformations and combinations (5-8 page illustrated texts) } \\
\text { - Adequate language for linguistic analysis, discussion, elaboration, dialogic inquiry, roleplays, } \\
\text { - etc. } \\
\text { - Multifunctional material to develop various communicative skills - reading, writing, } \\
\text { - Multimodal way of presenting the material (texts, colourful pictures, diagrams and other } \\
\text { - visuals) }\end{array}$ \\
\hline \multicolumn{3}{|c|}{ 2. Creative process support } \\
\hline & $\begin{array}{l}\text { Creative } \\
\text { thinking tools, } \\
\text { techniques and } \\
\text { software }\end{array}$ & $\begin{array}{l}\text { - Learning by teamwork - sharing knowledge and collaborating } \\
\text { - Brainstorming } \\
\text { - Synectics (metaphors, analogies) } \\
\text { - De Bono lateral thinking techniques (de Bono, 1993) } \\
\text { - ThinkTank }{ }^{\mathrm{TM}} \text { software for generation of ideas and further elaboration to find creative } \\
\text { solutions }\end{array}$ \\
\hline \multicolumn{3}{|c|}{ 3. Course administration } \\
\hline & $\begin{array}{l}\text { Selection of the } \\
\text { learning content }\end{array}$ & $\begin{array}{l}\text { - Consulting experts to choose the basic concepts and core knowledge to be acquired with } \\
\text { significant value in further studies, e.g. "Energy Sources", "Fossil Fuels", "Renewable Energy" }\end{array}$ \\
\hline 3.2 & User support & $\begin{array}{l}\text { - "Word assistant" tool to show translations, explanations, illustrations, and provide links for } \\
\text { further reading - discretely and on demand } \\
\text { - Guides, instructions and manuals } \\
\text { - Face-to-face consulting during classes }\end{array}$ \\
\hline 3.3 & $\begin{array}{l}\text { Software } \\
\text { environment }\end{array}$ & $\begin{array}{l}\text { - Blackboard }{ }^{\mathrm{TM}} \text { software to organize the course materials produced in HTML and to provide } \\
\text { basic assessment }\end{array}$ \\
\hline & $\begin{array}{l}\text { Assessment } \\
\text { techniques }\end{array}$ & $\begin{array}{l}\text { - Individual and collaborative problem solving tasks and achievement tests to assess student } \\
\text { creativity and acquaintance with the course material }\end{array}$ \\
\hline
\end{tabular}

The unconventional part of the "Creative learning of ESP" course was delivered with two distinct software solutions. The Blackboard (Blackboard Inc.) software environment was used for the delivery of learning material, basic performance assessment, user support, task information, 
and task feedback among other things, while ThinkTank ${ }^{\mathrm{TM}}$ (Groupsystems company) was used primarily for problem solving tasks which required creative collaboration. A total of 43 first-year students of the Faculty of Electrical and Power Engineering, RTU, took part in the course.

During the $1^{\text {st }}$ term the online texts were focusing on the basic tendencies in the application of renewable energy sources, highlighting also the duties and functions of a modern engineer (see Figure 1).

Figure 1. The template of the ESP course on the recent trends in the use of energy sources.

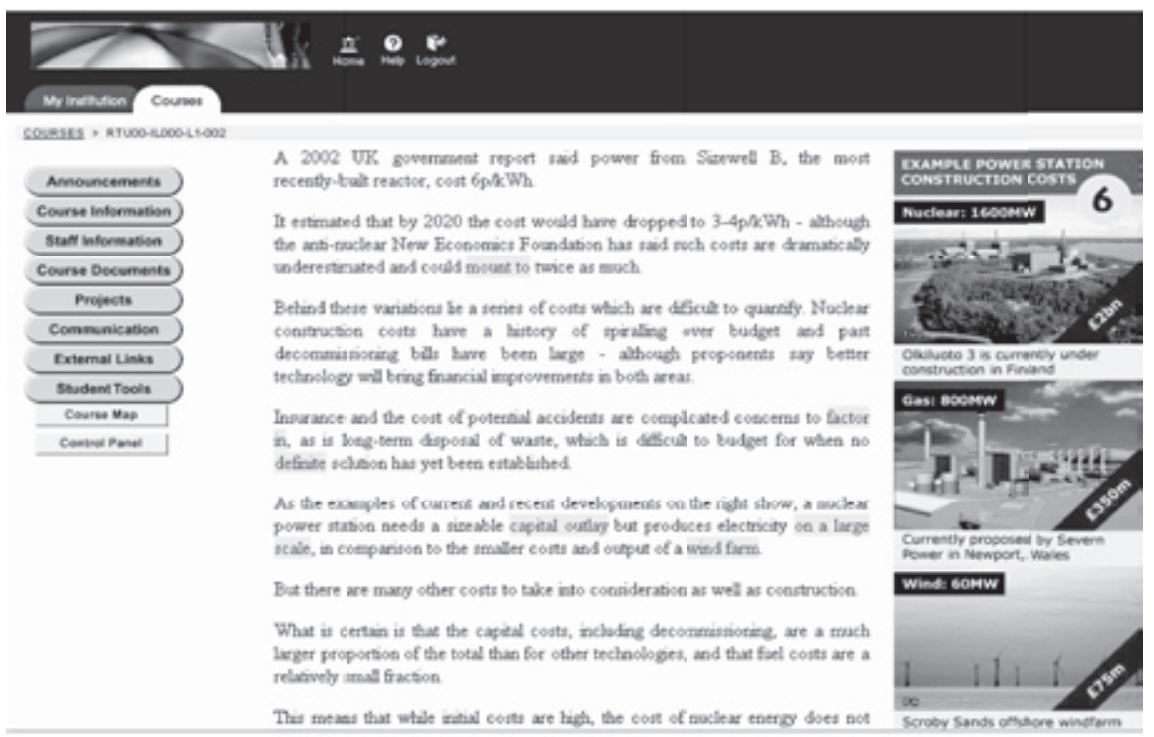

The course developers paid particular attention to the selection and adequate, professional explanation of the terminology by implementing the Word Assistant tool (see Figure 2). The terminology was selected on the frequency principle which would allow the students to move further independently when starting their professional careers.

Figure 2. The use of Word Assistant tool in mastering terminology online.

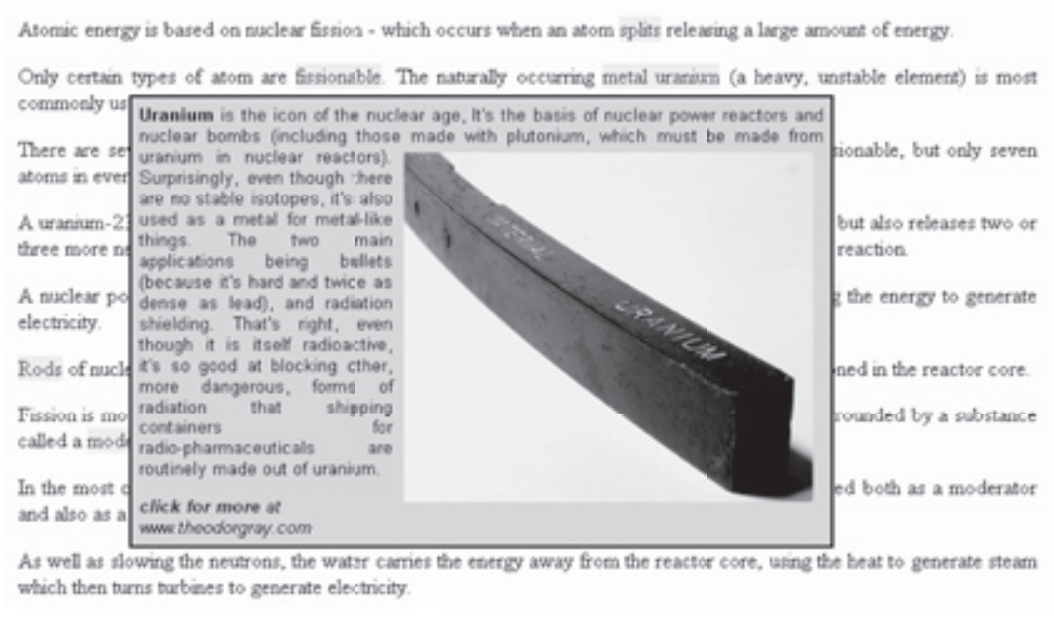


All the update of the tasks was available on the online course Discussion Board (see Figure 3), but the creative problem tasks done - in the online students' portfolio (see Figure 4).

Figure 3. Online Discussion Board.

\begin{abstract}
5. Creativity Unit Available
Creativity Unit is now arailable in the Course Documents section. We encourage you to get acquainted with it as soon as possible. As early as this week some groups will start working with the ThinkTank software and attempt to find creative solutions to various topical problems using a combination of different creativity techniques

Students are advised to see the ThinkTank Quick Start Guide for information and guidance regarding this sotware tool. This document can se found in the Creativity Unit

Unit 4 Riga Technical Universily and the European Union awailable

Unit 4 on Riga Technical University and the European Union is now available. As usual, printable and online versions are at your disposal.

Your Europe material is particulary useful for those who plan to study or work anywhere in the EU.

Word Assistant Updated - Unit 3 Reanty

Unit 3 (Guide to Nuclear Power is now supported toe along with urits 1 and 2. As usual, fithere are any words you think should have been explained or translated but were not, plrase go to the Discussion Boand and write your suggestions.

Werd Assistant is a simple tool trat is available for the online versions of our main articles (e.g. Global Energy Guide, Electrical Engineering). It works automatically when the cursor is moved over a highilted word, phrase or even some pictures and displays a translation, some useful information or commentaries. The Word Assistant has been implemented to make your studies online more elegand and simple
\end{abstract}

Figure 4. Portfolio with creative problem solving tasks.

\begin{abstract}
INFO RRETHOS PST REBNO4 TT REEO0 PST REBO0 TI RECOOTI ESSAYS
01: Nuclear fuel produces about as much fear and anxiety these days as it prodeces energy. If you had to set up a demonstration (display) to make people love it, what would your demenstration be like?

M

The goal of the demonstration is to inform people about the developenent of exclear energy. Badly informed people think that this source of energy is dangerous; expensive and is bad for the environment we must show the other side of the maclear power, that it is highly competitive, rather cheap in production, resources are abundact and in the future it will be safer. The demonstration has to be masive, peaceful and it has to last not for a day or a month but at least for a year, so we could show all the information we bave. If we want to achieve something positive we must get the support froen the governmert, scientiats, famous people, because their influence and popularity in the society will play a major role in the

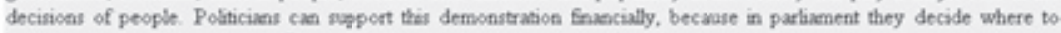
invest money and where not to. Posters and booklets are necessary, sions, labels and balloons with some text of pictures can be offered to the participants, furtler to everyone on the streets. In booklets everything has to be mentioned and explained, without difficult terminology, advantages and disadvantages must be written, because this way we show our
\end{abstract}

\title{
Creative collaboration using the ThinkTank ${ }^{\mathrm{TM}}$ software
}

Four distinct open-ended problem solving tasks were developed for use with the ThinkTank ${ }^{\mathrm{TM}}$ software. These sessions were held to one group and no more than 22 students at a time. Each session was limited to 80 minutes with groups working synchronously. A moderator oversaw the process assisting students where necessary.

The tasks focused on different social and economic challenges:

1) purely entrepreneurial - "New Business Challenge"

2) purely public opinion - "Public Opinion Challenge"

3) entrepreneur dependant on public opinion - "Market Sentiment Challenge"

4) social behaviour - "Lifestyle Challenge".

The problem solving process was anonymous and consisted of four stages for every task:

1) brainstorming - producing ideas

2) categorizing - isolating a particular group of ideas 
3) voting on various criteria - finding where the consensus or disagreement lies

4) evaluating the results - done at the end of each session and the results were published in the Blackboard ${ }^{\mathrm{TM}}$ environment as part of the student portfolio.

Students began with the "New Business Challenge" featuring a vivid language with similes to encourage creativity. They took the role of a businessman operating a small hydroelectric power plant dependant on government subsidies which had stopped and electricity production could no longer remain profitable. Another task - 'Lifestyle Challenge", focused on social responsibility and encouraged students to explore the dilemma of conspicuous consumption. The arguments speaking against it such as consequential environmental pollution and wasting of precious resources were presented, while, at the same time, recognizing that it has always been human nature to display one's wealth and social status by acquiring expensive commodities. The task was to think of activities motivating people to display their wealth and status by more socially conscious activities such as environmental protection, devotion to social issues, etc. Some of the solutions offered, their divergence and the consensus reached are depicted in Figure 5.

Figure 5. The criteria totals and the average divergence in solving the task 'Lifestyle Challenge' in the ThinkTank collaborative session.

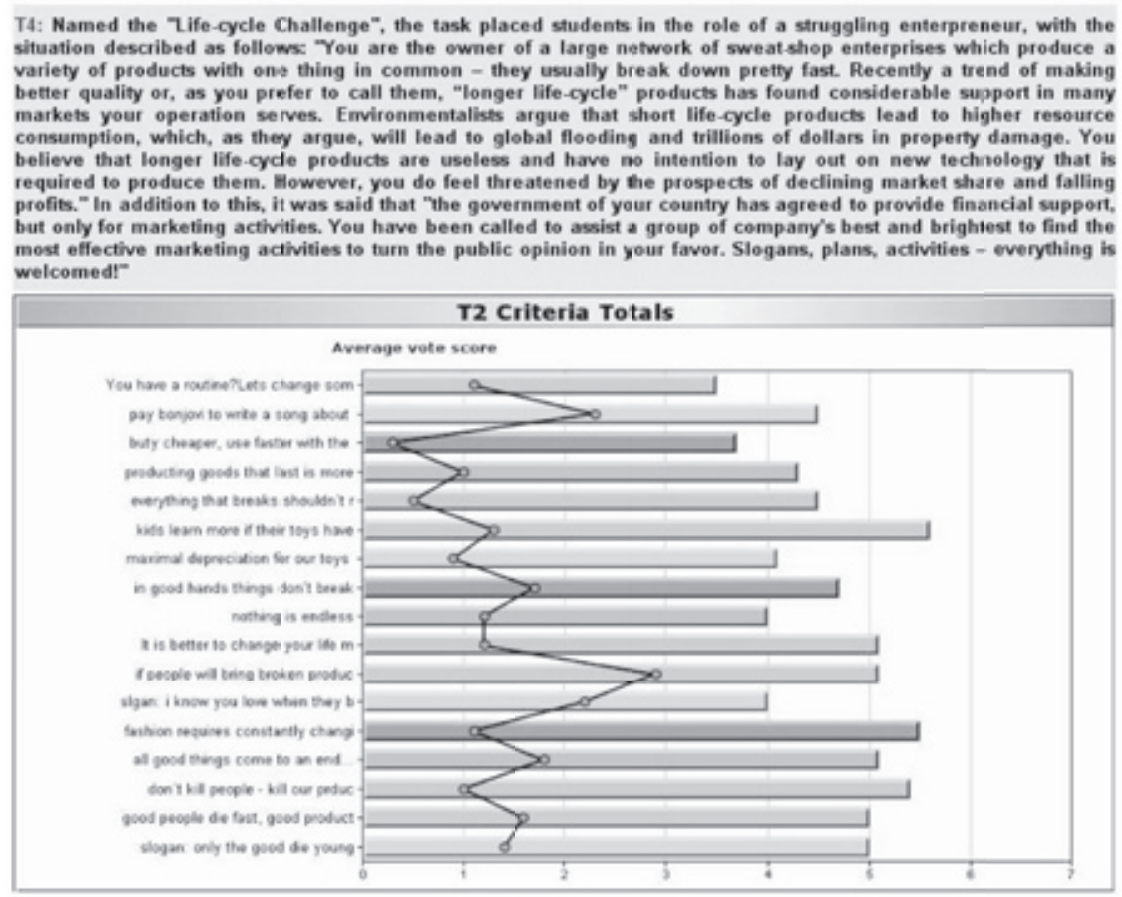

Creativity of the solutions was later analyzed considering the criteria of fluency, flexibility, originality, and elaboration (Torrance, 1974; Туник, 2002). Fluency implies the ability to produce a large amount of ideas, flexibility - to produce a broad variety of ideas, to use a variety of strategies, or shift from one approach to another, originality is the ability to produce ideas away from the obvious, commonplace, banal or established, elaboration characterizes the ability to develop, carry out or otherwise elaborate on ideas. 


\section{Results}

One of the assignments was completed both without group collaboration software and later with it which makes a direct comparison of the software and non-software approaches possible for a small number of students who did not take part in the prior task. Compared to the average results of the non-software approach by the rest of the participants, these students were more creative which could be attributed to use of sophisticated group collaboration software. A poll was also conducted and showed that students who participated in the group collaboration tasks thought that they had more motivation throughout the course than they would have had without these activities.

While the results are encouraging, it is important to note that a period of only three months may not be enough to observe immediate changes in creative abilities of the students. The author believes, however, that the specific creative and collaborative activities illustrated above and used in the course of "Creative Learning of ESP" could be integrated into other e-learning efforts to improve learners' self organization, foster creativity and decrease course dropout rates.

\section{Conclusions}

The author concludes that there are many reasons to undertake a deliberate effort to foster learners' creativity in e-learning courses. In this respect the research project supported by the Ministry of Education and Science, Latvia, and Riga Technical University, turned out to be most valuable (project developers: Diana Rumpite (supervisor), Bruno Zuga, Gunars Ritins, Liga Mangusa - RTU; Irina Surkova, University of Latvia). The results of the research showed that by applying the methodological principles of activity theory in structuring the course content and providing a student-centered pedagogical environment stimulated student creative thinking skills, as well as their English language proficiency.

During the development of the online course it became apparent that many commercial products were marketed as supporting a collaborative workflow, only few of which, however, were suitable to be used for sophisticated creative activities. Special tasks had to be developed and creative collaboration activities added significantly to the cost of the e-learning course. If comparable software is used, larger projects are bound to suffer from excessive costs of user support and course administration. Nevertheless, the author concludes that the approach of integrating commercially available group collaboration software with an e-learning course is feasible for smaller projects.

The author believes that e-learning will play a key role in delivering educational services in the near future and in recognizing the individual's creative potential and the importance of human creativity in any e-learning initiative.

\section{REFERENCES}

1. Benfield G., Francis R. (2005) Perspectives on E-Learning at Brookes. Brookes e-Journal of Learning and

2. Bono E. (1996) Serious Creativity. UK: Harper Collins Publishers, 338 p.

3. Craft A. (2001) Analysis of Research and Literature on Creativity in Education.

4. Csikszentmihalyi M. (1997) Creativity. Flow and the Psychology of Discovery and Invention. New York: Harper Perennial, $456 \mathrm{p}$.

5. Davydov V. V. (1999) A New Approach to the Interpretation of Activity Structure and Content. Activity Theory and Social Practice: Cultural-Historical Approaches. Aarhus: Aarhus University Press, p. 39-50.

6. Engestrom et. al. (Ed.) (1999) Perspectives on Activity Theory. N.Y.: Cambridge University Press, 463 p.

7. Jackson N. (2006) Creativity in Higher Education. SCEPTrE Scholarly Paper 3: March, p. 1-25. http:// portal.surrey.ac.uk (01.11.2007.) 
8. Lantolf J. P., et. al. (2006) Sociocultural Theory and the Genesis of Second Language Development. Oxford University Press, $398 \mathrm{p}$.

9. Laurillard D. (2002) Rethinking University Teaching: a Conversational Framework for the Effective Use of Learning Technologies. $2^{\text {nd }}$ ed. London, New York: Routledge Falmer, 268 p.

10. Lindquist G. (2003) Vygotsky's Theory of Creativity. In Creativity Research Journal, Vol. 15, No. 2, 3, p. $245-251$.

11. Lompscher J. (1999) Activity Formation as an Alternative Strategy of Instruction. Engestrom Y. (Ed.). Perspectives on Activity Theory. Cambridge: Cambridge University Press, p. 264-281.

12. Moran S., John-Steiner V. (2003) Creativity in the Making. Vygotsky's Contemporary Contribution to the Dialectic of Development and Creativity. In. Sawyer R. K., Steiner V. J., et. al. (Eds.) Creativity and Development. Oxford University Press, p. 61-91.

13. Porter D. (2006) Innovations, Trends, and Creativity in Distance Education. Paper presented at the $4^{\text {th }}$ International Congress on Education and Technology - Inter-American University of Puerto Rico (UIPR). Sept. 7, 2006, p. 1-11. http://www.bccampus.ca (01.11.2007.)

14. Rumpìte D. (1998) Vigotska idejas svešvalodu apguvē. Starptautiskās konferences materiālu krājums Luevs Vigotskis, Žans Piažē un mūsdienu psihologija. Rīga: RaKa, 136.-141. lpp.

15. Rumpite D. (2000) Novitātes kreativitātes teorijā. Skolotājs, Nr 5, 32.-38. lpp.

16. Rumpite D., Zuga B., Ritins G. (2007) Development of Online Course Design and Development Approach in Creative Learning of English for Specific Purposes. Research Papers of the International Nordic-Baltic Conference of the World Federation of Language Teacher Associations (FIPLV). Rìga: Izglìīibas soḷi, p. 298.-308.

17. Runco M. A., Pritzker S. R. (Eds.) (1999) Encyclopedia of Creativity. Vol. 1, 2. London: Academic Press, 810 p.

18. Sternberg R. J., Lubart T. I. (1999) The Concept of Creativity: Prospects and Paradigms. Sternberg R.J. (Ed.). Handbook of Creativity. New York: Cambridge University Press, p. 3-15.

19. Torrance E. P. (1974) Torrance Tests of Creative Thinking. Lexington: Personnel Press, Inc., 47 p.

20. Torrance E. P. (1983) Creativity in the Classroom. N. Y.: National Education Association of the United States, $36 \mathrm{p}$.

21. Vygotsky L. (1999) Thought and Language. Cambridge: the MIT Press, 287 p.

22. Vygotsky L. (1978) Mind in Society. The Development of Higher Psychological Processes. Cambridge: Harward University Press, 159 p.

23. Wells G. (2002) Learning and Teaching for Understanding: the Key Role of Collaborative Knowledge Building. http://people.ucsc.edu/ gwells/ (01.11.2007.)

24. Гальперин П. Я. (2000) Введение в психологию. Москва: МГУ, 330 с.

25. Давыдов В. В. (1996) Теория развивающего обучения. Москва: Педагогика, 539 с.

26. Леонтьев А. Н. (1977) Деятельность. Сознание. Личность. Москва: Политическая литература, $304 \mathrm{c}$.

27. Туник Е. Е. (2002) Тест Е. Торренса. Диагностика креативности. Методическое руководство. Санкт- Петербург: Гп, Иматон, 191 с.

Asoc. prof. Dr. paed. Diāna Rumpīte

Riga Technical University

Address: Baznicas St. 26-43, Jurmala, LV-2015, Latvia

Phone: (+371) 29459164; Fax: (+371) 7089302

E-mail: rumpite@gmail.com 